\title{
Oxidative stability and storage quality analysis of Ocimum sanctum L. extracts incorporated chicken nuggets
}

\section{Tanuj Tanwar, Arvind Kumar* and Nrip Kishore Pankaj}

Faculty of Veterinary Sciences and Animal Husbandry, Division of Livestock Products Technology Sher-e-Kashmir University of Agricultural Sciences \& Technology of Jammu, Jammu-180009 (J\&K), INDIA *Corresponding author. E-mail: drarvindlpt@gmail.com

Received: April. 7, 2016; Revised received: September 17, 2016; Accepted: November 22, 2016

\begin{abstract}
The present study was done to explore the antioxidant potential of locally available herb holy basil viz. Ocimum sanctumL.. in enhancing the shelf-life of emulsion based chicken nuggets. Chicken nuggets are widely cherished meat cuisine but it is vulnerable to spoilage due to excessive fats and protein content. Thus, chicken nugget fortified with 1, 2, and $3 \%$ of itsethanolic-aqueous extracts of 0 . sanctum and along with control was studied to explore the potency of holy basil on oxidative stability and storage quality of chicken nuggets on $0,7,14$ and 21 days at refrigeration temperature. $80 \%$ ethanolic aqueous extracts of 0 . sanctum were prepared, standardized, optimized and incorporated in chicken nuggets. Chicken nuggets prepared with fortification of $3 \% 0$. sanctum extract were adjudged best among all with overall acceptability of $7.16 \pm 0.071$ value in sensory analysis. The 0 . sanctum extract treated chicken nugget's pH, FFA, TBA, Total plate count, Pychrophilic count, Yeast and Mold count were found to be in acceptable range of $4.49 \pm 0.008,0.320 \pm 0.0005,0.979 \pm 0.0012,<4,<2,<2 \log _{10} \mathrm{cfu} / \mathrm{g}$ respectively on 21 days of refrigeration storage. Extracts of $O$. sanctum fortified chicken nuggets were safe for human consumption even 21 days of refrigerated storage $\left(4 \pm 1^{\circ} \mathrm{C}\right)$ on the basis of $\mathrm{pH}$, FFA, TBA value, microbiological profile and sensory evaluation. The results proved the antioxidant potential of holy basil $O$. sanctumand chicken nuggets fortified with $(3 \%)$ Ocimum sanctum extract could be safe for a period of 21 days in refrigerated $\left(4 \pm 1^{\circ} \mathrm{C}\right)$ storage without any marked loss of physico-chemical, microbial and sensory quality.
\end{abstract}

Keywords: Antioxidant, Chicken nuggets, Ocimum sanctum, Oxidative stability, Storage quality

\section{INTRODUCTION}

Consumer demands for safe, natural and high quality foods. The preference of consumer towards natural or organic food compels the food industry to include natural antioxidant in meat products to impart oxidative stability (Camo et al., 2008). The herbal extract can act as a potent natural antioxidant which can be used in different meat products. The addiction of these extract not only improves the sensory characteristic but also enhance self-life (Wojdylo et al., 2007).

Most of the disease that we encounter today is lifestyle disease which also includes degenerative disease. The occurrence of these diseases is due to excessive formation of pro-oxidant (free radical and reactive oxygen species) metabolism in the body. To counter these pro-oxidant, the antioxidant are also secreted at cellular level but due to several reason like genetic factor, dietary habit, physiological status, work load and environment pollution etc. This is excessive production of pro-oxidant at cellular level which leads to oxidative damage of the cell resulting in various lifestyle diseases (diseases, cancer, cardiovascular disease, atherosclerosis, Alzheimer and Parkinson). Therefore in today's prospective natural antioxidants are essential dietary requirement thus development of value added meat product with incorporation of herbal extract as antioxidant of herbal extract as antioxidant help us in combating oxidative stress. (Tajkarimi et al., 2010)

Ocimum sanctum Linn. (Family: Labiatae), locally known as 'Tulsi' in Hindi and 'Holy Basil' in English, is herb found throughout India. The Indian herb $O$. sanctum - may serve as dietary antioxidant with various mode of action viz. anti-microbial agent, anti lipolytic agent. Therefore the extract of $O$. sanctum can elongate the shelf-life of meat product when incorporated at standardized and optimized level in emulsion based meat product. The extract of $O$. sanctum also act as antioxidant when consumed by humans and protect them from oxidative damaged and age old cognitive decline (Simpson et al., 2015). The aim of present study is to develop $O$. sanctum. extract incorporated value added meat product and further the product is evaluated for it quality parameters during refrigeration storage.

\section{MATERIALS AND METHODS}

Raw material: Spent hen meat of over 72 weeks age was selected. The spent hen was humanely slaughtered 
in the meat science lab of Division of Livestock Products Technology, SKUAST-Jammu. Ocimum sanctum L. were collected locally. It was further identified and authenticated by Department of Botany, Jammu University. Preparation of $\boldsymbol{O}$. sanctum extract: Fresh $O$. sanctum plant will be collected and botanically authenticated. The leaves will be separated and dried at $40^{\circ} \mathrm{C}$ for 6 hours in hot air oven. The dried leaves will be grounded into fine powder form. The powder will be dissolved in $80 \%$ ethanol aqueous solution for four days by changing solution daily. The extract will be filtered and evaporated to $10 \%$ dryness $\mathrm{v} / \mathrm{v}$ using rotatory evaporator (Hannan et al., 2006).

Preparation of chicken nuggets: Lean meat from spent hen was cut and minced in a meat mincer (MODTC 23 R10 U.P. INOX, Marsango, Italy). Meat emulsion for chicken nuggets was prepared in Sirman Bowl Chopper [MOD 25 2.8G 4.0, Marsango, Italy]. Crushed ice was added and blending continued for 1.5 minutes. Addition of refined vegetable oil, spice mixture, condiments and other ingredients and again mixed for 1.5 to 2 minutes to get the desired emulsion. Chicken nuggets were molded in rectangular stainless steel boxes. The steel boxes of $21 \mathrm{~cm}$ in length and 11 $\mathrm{cm}$ in breadth were used for molding and further steaming was done. The weighed quantity of the batter or emulsion was stuffed in mould with parchment paper and pre-smeared with oil to avoid sticking. Mold was covered with lid and tied properly. The mixture was subjected to steam cooking for $30 \pm 2$ minutes in pressure cooker. The boxes were allowed to cool at room temperature after removal from pressure cooker. The brick shaped chicken nugget so obtained were sliced and cut into pieces to get smaller nuggets. The formulation in (\%) was standardized, optimized and used for preparation of chicken nuggets from spent hen meat was lean meat- 68.6, added water-9.1, vegetable oil- 8.9 , condiment mixture-4.9, refined wheat flour 4.1, spice mixture-1.9, table salt-1.6, monosodium glutamate- 0.4 , sodium tripolyphosphate -0.4 , sodium nitrite $-100 \mathrm{ppm}, O$. sanctum 1,2 , and $3 \%$ extracts added with replacement in control chicken nuggets (wt./ wt.). The nuggets were cooled and then stored in low density polyethylene pouches (200 gauge).These were stored in refrigerator $\left(4 \pm 1^{\circ} \mathrm{C}\right)$ for evaluation of physicochemical and sensory parameters $0^{\text {th }}, 7^{\text {th }}, 14^{\text {th }}$ and $21^{\text {st }}$ day. Experimental design: The ethanolic-aqueous Ocimum sanctum L. extract was prepared and was added in standardized formulation of chicken nuggets substituting proportionately (wt./wt.) at the level of $1 \%, 2 \%$ and $3 \%$. The products were evaluated based on physicochemical, sensory and microbiological profile on $0^{\text {th }}, 7^{\text {th }}$, $14^{\text {th }}$ and $21^{\text {st }}$ day during refrigeration storage at $\left(4 \pm 1^{\circ} \mathrm{C}\right)$.

\section{Analytical techniques}

pH: The pH of cooked nuggets was measured soon after its preparation by the method of (Keller et al., 1974).

Moisture content: It was calculated as per method.
(AOAC, 1995).

Thio barbituric acid (TBA): It was determined using the method of (Witte et al., 1970).

Free fatty acid (FFA): The method described by (Koniecko, 1979) was followed.

Microbiological profile: Total plate count, Psychrotrophic count, Coliform count and Yeast and Mould count in the sample were determined by method described by (APHA, 1984). Readymade media (HiMedia) were used for the analysis.

Sensory evaluation: It was carried for various attributes viz. color and appearance, flavor, juiciness, texture and overall acceptability by a panel of trained members composed of scientists based on a eight-point Hedonic scale, wherein 8 denoted "extremely desirable" and 1 denoted "extremely undesirable" (Keeton et al., 1983). Seven members of the panel replicated the experiment thrice $(n=21)$. Panelists were comfortably seated in a room free of noise and odors and suitably illuminated. Coded samples for sensory evaluation were prepared.

Statistical analysis: The results were analyzed statistically for analysis of variance in one way as well as two way and least significant difference tests as per (Snedecor and Cochran, 1989). In significant effects, least significant differences were calculated for a pair wise comparison of treatment means.

\section{RESULTS AND DISCUSSION}

Physico-chemical parameters: The changes in physico-chemical profile of $O$. sanctum $s p$ extract fortified chicken nuggets at refrigeration temperature $\left(4 \pm 1^{\circ} \mathrm{C}\right)$ presented in Table 1 .

pH: The $\mathrm{pH}$ of $O$. sanctum extract incorporated chicken nuggets was recorded to be significantly lower as compared to control. The $\mathrm{pH}$ was increased significantly on successive storage days irrespective of levels of incorporation of $O$. sanctum extract in chicken nuggets including control. However the inclination in $\mathrm{pH}$ level was significantly lower in treated product as compared to control. It may be due to the fact that $O$. sanctum extract contains urolic acid, apigenin, and luteolin which are proton donors and acidic in nature. The poultry meat recorded lower $\mathrm{pH}$ when fed on diet incorporated with $O$. sanctum powder Lanjewar et al. (2009). The acidic pH of $O$. sanctum extract was helpful in treatment of wilt disease of tomato plant (Murthy et al., 2014).

Moisture: The moisture level recorded in O. sanctum extract incorporated chicken nuggets and control was comparable. This may be due to the fact that the extract prepared contains similar moisture levels as present in meat emulsion. However, the moisture level observed in $O$. sanctum extract incorporated chicken nuggets and control decreased significantly $(\mathrm{p}<0.05)$ on successive refrigeration storage days. This fact was supported by the finding of (Shan et al., 2005; Wojdy- 
Tanuj Tanwar et al. / J. Appl. \& Nat. Sci. 8 (4): 2182-2188 (2016)

Table 1. Changes in physico-chemical profile of Ocimum sanctum extract fortified chicken nuggets at refrigeration temperature $\left(4 \pm 1^{0} \mathrm{C}\right)$. (Mean $\left.\pm \mathrm{SE}\right)^{*}$.

\begin{tabular}{|c|c|c|c|c|}
\hline TREATMENTS & 0-day & $7^{\text {th }}$ day & $14^{\text {th }}$-day & $21^{\text {st }}$-day \\
\hline \multicolumn{5}{|c|}{$\mathrm{pH}$} \\
\hline O.sanctum (Control) & $5.88 \pm 0.007^{\mathrm{Ad}}$ & $5.97 \pm 0.009^{\mathrm{Ac}}$ & $6.26 \pm 0.011^{\mathrm{Ab}}$ & $6.73 \pm 0.005^{\mathrm{Aa}}$ \\
\hline O.sanctum $(1 \%)$ & $5.85 \pm 0.166^{\mathrm{ABd}}$ & $5.87 \pm 0.009^{\mathrm{Bc}}$ & $6.11 \pm 0.011^{\mathrm{Bb}}$ & $6.49 \pm 0.008^{\mathrm{Ba}}$ \\
\hline O.sanctum (2\%) & $5.82 \pm 0.133^{\mathrm{BCd}}$ & $5.73 \pm 0.010^{\mathrm{Cc}}$ & $6.02 \pm 0.007^{\mathrm{Cb}}$ & $6.36 \pm 0.008^{\mathrm{Ca}}$ \\
\hline O.sanctum (3\%) & $5.79 \pm 0.170^{\mathrm{Cd}}$ & $5.49 \pm 0.009^{\mathrm{Dc}}$ & $5.59 \pm 0.005^{\mathrm{Db}}$ & $6.30 \pm 0.008^{\mathrm{Da}}$ \\
\hline \multicolumn{5}{|c|}{ Moisture } \\
\hline O.sanctum (Control) & $61.77 \pm 0.679^{\mathrm{Aa}}$ & $60.51 \pm 0.575^{\text {Aab }}$ & $59.94 \pm 0.334^{\mathrm{Aab}}$ & $58.82 \pm 0.688^{\mathrm{Ab}}$ \\
\hline O.sanctum $(1 \%)$ & $61.92 \pm 0.333^{\mathrm{Aa}}$ & $60.76 \pm 0.329^{\mathrm{Aab}}$ & $60.02 \pm 0.692^{\mathrm{Abc}}$ & $58.90 \pm 0.329^{\mathrm{Ac}}$ \\
\hline O.sanctum (2\%) & $61.02 \pm 0.494^{\mathrm{Aa}}$ & $60.81 \pm 0.375^{\mathrm{Aab}}$ & $60.05 \pm 0372^{\mathrm{Abc}}$ & $58.14 \pm 0.359^{\mathrm{Ac}}$ \\
\hline O.sanctum $(3 \%)$ & $61.34 \pm 0.519^{\mathrm{Aa}}$ & $60.41 \pm 0.494^{\mathrm{Aab}}$ & $60.52 \pm 0.514^{\mathrm{Abc}}$ & $58.52 \pm 0.505^{\mathrm{Ac}}$ \\
\hline \multicolumn{5}{|c|}{ TBA (mg malonaldehyde/kg) } \\
\hline O.sanctum (Control) & $0.302 \pm 0.0134^{\mathrm{Ad}}$ & $0.429 \pm 0.0005^{\mathrm{Ac}}$ & $1.051 \pm 0.0011^{\mathrm{Ab}}$ & $1.305 \pm 0.0005^{\mathrm{Aa}}$ \\
\hline O.sanctum $(1 \%)$ & $0.298 \pm 0.0182^{\mathrm{ABd}}$ & $0.394 \pm 0.0009^{\mathrm{Bc}}$ & $0.674 \pm 0.0006^{\mathrm{Bb}}$ & $1.250 \pm 0.0012^{\mathrm{Ba}}$ \\
\hline O.sanctum (2\%) & $0.293 \pm 0.0280^{\mathrm{BCd}}$ & $0.362 \pm 0.0005^{\mathrm{Cc}}$ & $0.625 \pm 0.0007^{\mathrm{Cb}}$ & $1.221 \pm 0.0005^{\mathrm{Ca}}$ \\
\hline O.sanctum $(3 \%)$ & $0.289 \pm 0.0145^{\mathrm{Ca}}$ & $0.325 \pm 0.0005^{\mathrm{Dc}}$ & $0.561 \pm 0.0007^{\mathrm{Db}}$ & $1.161 \pm 0.005^{\mathrm{Dd}}$ \\
\hline \multicolumn{5}{|c|}{ FFA (\% oleic acid) } \\
\hline O.sanctum (Control) & $0.093 \pm 0.0005^{\mathrm{Ad}}$ & $0.135 \pm 0.0008^{\mathrm{Ac}}$ & $0.225 \pm 0.0005^{\mathrm{Ab}}$ & $0.362 \pm 0.0006^{\mathrm{Aa}}$ \\
\hline O.sanctum $(1 \%)$ & $0.091 \pm 0.0063^{\mathrm{Ad}}$ & $0.115 \pm 0.0009^{\mathrm{Bc}}$ & $0.205 \pm 0.0009^{\mathrm{Bb}}$ & $0.320 \pm 0.0005^{\mathrm{Ba}}$ \\
\hline O.sanctum (2\%) & $0.085 \pm 0.0140^{\mathrm{Bd}}$ & $0.095 \pm 0.0008^{\mathrm{Cc}}$ & $0.180 \pm 0.0008^{\mathrm{Cb}}$ & $0.234 \pm 0.0009^{\mathrm{Ca}}$ \\
\hline O.sanctum $(3 \%)$ & $0.080 \pm 0.0217^{\mathrm{Cd}}$ & $0.076 \pm 0.0008^{\mathrm{Cc}}$ & $0.131 \pm 0.0007^{\mathrm{Cb}}$ & $0.215 \pm 0.0047^{\mathrm{Ca}}$ \\
\hline
\end{tabular}

*Mean \pm SE with different superscripts in a row wise (lower case alphabet) and column wise (upper case alphabet) differ significantly $(\mathrm{P}<0.05) . \mathrm{n}=6$ for each treatment.

Table 2. Changes in microbiological profile of Ocimum sanctum extract fortified chicken nuggets at refrigeration temperature $\left(4 \pm 1^{0} \mathrm{C}\right) .(\text { Mean } \pm \mathrm{SE})^{*}$

\begin{tabular}{|c|c|c|c|c|}
\hline TREATMENTS & 0-day & $7^{\text {th }}$ day & $14^{\text {th }}$-day & $21^{\text {st }}$-day \\
\hline \multicolumn{5}{|c|}{ Total Plate Count $\left(\log _{10} \mathrm{cfu} / \mathrm{g}\right)$} \\
\hline O.sanctum (Control) & $2.70 \pm 0.0076^{\mathrm{Ad}}$ & $3.74 \pm 0.0088^{\mathrm{Ac}}$ & $4.15 \pm 0.0114^{\mathrm{Ab}}$ & $5.10 \pm 0.0076^{\mathrm{Aa}}$ \\
\hline O.sanctum $(1 \%)$ & $2.35 \pm 0.0073^{\mathrm{Bd}}$ & $3.29 \pm 0.0111^{\mathrm{Bc}}$ & $3.85 \pm 0.0076^{\mathrm{Bb}}$ & $4.35 \pm 0.0096^{\mathrm{Ba}}$ \\
\hline O.sanctum (2\%) & $1.80 \pm 0.0066^{\mathrm{Cd}}$ & $3.10 \pm 0.0076^{\mathrm{Cc}}$ & $3.50 \pm 0.0101^{\mathrm{Cb}}$ & $3.72 \pm 0.0076^{\mathrm{Ca}}$ \\
\hline O.sanctum $(3 \%)$ & $1.79 \pm 0.0057^{\mathrm{Dd}}$ & $2.88 \pm 0.0080^{\mathrm{Dc}}$ & $3.15 \pm 0.0060^{\mathrm{Db}}$ & $3.49 \pm 0.0060^{\mathrm{Da}}$ \\
\hline \multicolumn{5}{|c|}{ Psychrophilic count $\left(\log _{10} \mathrm{cfu} / \mathrm{g}\right)$} \\
\hline O.sanctum (Control) & ND & ND & $1.59 \pm 0.011^{\mathrm{Ab}}$ & $2.74 \pm 0.0152^{\mathrm{Aa}}$ \\
\hline O.sanctum $(1 \%)$ & ND & ND & $1.34 \pm 0.360^{\mathrm{Bb}}$ & $2.26 \pm 0.0125^{\mathrm{Ba}}$ \\
\hline O.sanctum $(2 \%)$ & ND & ND & $0.98 \pm 0.013^{\mathrm{Cb}}$ & $1.84 \pm 0.0116^{\mathrm{Ca}}$ \\
\hline O.sanctum $(3 \%)$ & ND & ND & $0.70 \pm 0.007^{\mathrm{Db}}$ & $1.21 \pm 0.0116^{\mathrm{Da}}$ \\
\hline \multicolumn{5}{|c|}{ Coliform count $\left(\log _{10} \mathrm{cfu} / \mathrm{g}\right)$} \\
\hline O.sanctum (Control) & ND & ND & ND & ND \\
\hline O.sanctum $(1 \%)$ & ND & ND & ND & ND \\
\hline O.sanctum $(2 \%)$ & ND & ND & ND & ND \\
\hline O.sanctum $(3 \%)$ & ND & ND & ND & ND \\
\hline \multicolumn{5}{|c|}{ Yeast and Mold count $\left(\log _{10} \mathrm{cfu} / \mathrm{g}\right)$} \\
\hline O.sanctum (Control) & ND & ND & $2.73 \pm 0.0101^{\mathrm{Ab}}$ & $3.60 \pm 0.0110^{\mathrm{Aa}}$ \\
\hline O.sanctum $(1 \%)$ & ND & ND & $2.40 \pm 0.0114^{\mathrm{Bb}}$ & $3.20 \pm 0.0076^{\mathrm{Ba}}$ \\
\hline O.sanctum $(2 \%)$ & ND & ND & $2.09 \pm 0.1344^{\mathrm{Cb}}$ & $2.79 \pm 0.0107^{\mathrm{Ca}}$ \\
\hline O.sanctum $(3 \%)$ & ND & ND & $1.71 \pm 0.0105^{\mathrm{Db}}$ & $2.34 \pm 0.0125^{\mathrm{Da}}$ \\
\hline
\end{tabular}

*Mean $\pm \mathrm{SE}$ with different superscripts in a row wise (lower case alphabet) and column wise (upper case alphabet) differ significantly $(\mathrm{P}<0.05) . \mathrm{n}=6$ for each treatment.

olo et al., 2007; Lanjewar et al., 2009) who worked on Indian holy basil (Ocimum sanctum sp), oregano (Organum vulgare L.), rosemary (Rosmarinus offici- nalis L.) and sage (Salvia officinalis L.) in various emulsion based meat products.

TBA value: The TBA value is quantitative indication 
Table 3. Changes in the sensory attributes of aerobically packaged Ocimum sanctum extract incorporated chicken nuggets during refrigerated storage at $4 \pm 1^{\circ} \mathrm{C}(\text { Mean } \pm \mathrm{SE})^{*}$.

\begin{tabular}{|c|c|c|c|c|}
\hline \multirow{2}{*}{ TREATMENTS } & \multicolumn{4}{|c|}{$\begin{array}{l}\text { STORAGE PERIOD (DAYS) } \\
\end{array}$} \\
\hline & 0 Day & $7^{\text {th }}$-DAY & $14^{\text {th }}-\mathrm{DAY}$ & $21^{\text {th }}-0 D A Y$ \\
\hline \multicolumn{5}{|c|}{ Colour and appearance } \\
\hline O.sanctum (Control) & $6.69 \pm 0.100^{\mathrm{Ca}}$ & $6.07 \pm 0.099^{\mathrm{Cb}}$ & $5.59 \pm 0.107^{\mathrm{Dc}}$ & $4.95 \pm 0.131^{\mathrm{Ad}}$ \\
\hline O.sanctum $(1 \%)$ & $7.02 \pm 0.116^{\mathrm{Ba}}$ & $6.52 \pm 0.106^{\mathrm{Bb}}$ & $6.02 \pm 0.080^{\mathrm{Bc}}$ & $5.40 \pm 0.131^{\mathrm{Bd}}$ \\
\hline O.sanctum $(2 \%)$ & $7.45 \pm 0.108^{\mathrm{Aa}}$ & $6.95 \pm 0.083^{\mathrm{Ab}}$ & $6.42 \pm 0.086^{\mathrm{Ac}}$ & $5.97 \pm 0.080^{\mathrm{Ad}}$ \\
\hline O.sanctum $(3 \%)$ & $6.38 \pm 0.076^{\mathrm{Da}}$ & $5.78 \pm 0.106^{\mathrm{Db}}$ & $5.28 \pm 0.112^{\mathrm{Cc}}$ & $4.54 \pm 0.137^{\text {Dd }}$ \\
\hline \multicolumn{5}{|c|}{ Flavour } \\
\hline O.sanctum (Control) & $6.52 \pm 0.094^{\mathrm{Ba}}$ & $5.92 \pm 0.130^{\mathrm{Bb}}$ & $5.59 \pm 0.074^{\mathrm{Bc}}$ & $3.95 \pm 0.108^{\mathrm{Bd}}$ \\
\hline O.sanctum $(1 \%)$ & $6.73 \pm 0.131^{\mathrm{Ba}}$ & $6.11 \pm 0.119^{\mathrm{Bb}}$ & $5.76 \pm 0.112^{\mathrm{Bc}}$ & $4.07 \pm 0.105^{\mathrm{Bd}}$ \\
\hline O.sanctum (2\%) & $6.76 \pm 0.081^{\mathrm{Ba}}$ & $6.21 \pm 0.073^{\mathrm{Bb}}$ & $5.88 \pm 0.113^{\mathrm{Bc}}$ & $4.14 \pm 0.070^{\mathrm{Bd}}$ \\
\hline O.sanctum (3\%) & $7.14 \pm 0.098^{\mathrm{Aa}}$ & $6.73 \pm 0.061^{\mathrm{Ab}}$ & $6.33 \pm 0.061^{\mathrm{Ac}}$ & $4.83 \pm 0.076^{\mathrm{Ad}}$ \\
\hline \multicolumn{5}{|c|}{ Texture } \\
\hline O.sanctum (Control) & $7.40 \pm 0.088^{\mathrm{Aa}}$ & $6.83 \pm 0.105^{\mathrm{Ab}}$ & $5.57 \pm 0.086^{\mathrm{Ac}}$ & $4.61 \pm 0.102^{\mathrm{Ad}}$ \\
\hline O.sanctum $(\%)$ & $7.42 \pm 0.110^{\mathrm{Aa}}$ & $6.88 \pm 0.137^{\mathrm{Ab}}$ & $5.64 \pm 0.092^{\mathrm{Ac}}$ & $4.66 \pm 0.130^{\mathrm{Ad}}$ \\
\hline O.sanctum (2\%) & $7.50 \pm 0.912^{\mathrm{Aa}}$ & $6.97 \pm 0.126^{\mathrm{Ab}}$ & $5.71 \pm 0.127^{\mathrm{Ac}}$ & $4.76 \pm 0.136^{\mathrm{Ac}}$ \\
\hline O.sanctum $(3 \%)$ & $7.38 \pm 0.076^{\mathrm{Aa}}$ & $6.76 \pm 0.101^{\mathrm{Ab}}$ & $5.52 \pm 0.087^{\mathrm{Ac}}$ & $4.59 \pm 0.062^{\mathrm{Ac}}$ \\
\hline \multicolumn{5}{|c|}{ Juiciness } \\
\hline O.sanctum (Control) & $6.80 \pm 0.100^{\mathrm{Ca}}$ & $6.33 \pm 0.105^{\mathrm{Cb}}$ & $5.59 \pm 0.127^{\mathrm{Cc}}$ & $4.88 \pm 0.090^{\mathrm{Cd}}$ \\
\hline O.sanctum (1\%) & $7.04 \pm 0.083^{\mathrm{BCa}}$ & $6.54 \pm 0.108^{\mathrm{BCb}}$ & $5.85 \pm 0.115^{\mathrm{BCc}}$ & $5.11 \pm 0.074^{\mathrm{BCd}}$ \\
\hline O.sanctum (2\%) & $7.16 \pm 0.110^{\mathrm{Ba}}$ & $6.66 \pm 0.099^{\mathrm{Bb}}$ & $5.97 \pm 0.094^{\mathrm{Bc}}$ & $5.21 \pm 0.100^{\mathrm{Bd}}$ \\
\hline O.sanctum (3\%) & $7.47 \pm 0.080^{\mathrm{Aa}}$ & $6.97 \pm 0.094^{\mathrm{Ab}}$ & $6.40 \pm 0.101^{\mathrm{Ac}}$ & $5.52 \pm 0.050^{\mathrm{Ad}}$ \\
\hline \multicolumn{5}{|c|}{ Overall acceptability } \\
\hline O.sanctum (Control) & $6.85 \pm 0.104^{\mathrm{Ca}}$ & $6.21 \pm 0.073^{\mathrm{Cb}}$ & $5.40 \pm 0.144^{\mathrm{Cc}}$ & $3.97 \pm 0.116^{\mathrm{Cd}}$ \\
\hline O.sanctum (1\%) & $6.97 \pm 0.116^{\mathrm{Ca}}$ & $6.33 \pm 0.079^{\mathrm{Cb}}$ & $5.54 \pm 0.113^{\mathrm{Cc}}$ & $4.16 \pm 0.062^{\mathrm{Cd}}$ \\
\hline O.sanctum (2\%) & $7.26 \pm 0.065^{\mathrm{Ba}}$ & $6.73 \pm 0.117^{\mathrm{Bb}}$ & $5.93 \pm 0.086^{\mathrm{Bc}}$ & $4.57 \pm 0.115^{\mathrm{Bd}}$ \\
\hline O.sanctum (3\%) & $7.54 \pm 0.090^{\mathrm{Aa}}$ & $7.16 \pm 0.071^{\mathrm{Ab}}$ & $6.33 \pm 0.093^{\mathrm{Ac}}$ & $5.00 \pm 0.091^{\mathrm{Ad}}$ \\
\hline
\end{tabular}

*Mean \pm SE with different superscripts in a row wise (lower case alphabet) and column wise (upper case alphabet) differ significantly $(\mathrm{P}<0.05)$. Mean values are scores on 8 point descriptive scale where 1 - extremely poor and 8 - extremely desirable. $\mathrm{n}=$ 21 for each treatment.

of lipid peroxidation in meat products. In order to know the rate of lipid peroxidation, the malondialdehyde content was evaluated by assaying meat product during storage. TBA value was significantly $(\mathrm{p}<0.05)$ decreased with increased in the level of incorporation of $O$. sanctum extract while it was found to be significantly $(\mathrm{p}<0.05)$ increased on successive storage days in $O$. sanctum extract incorporated chicken nuggets including control. The TBA value indicated that control chicken nugget was not suitable for consumption on $21^{\text {st }}$ day of refrigeration storage whereas all levels of $O$. sanctum. extract incorporated chicken nugget was found to be suitable for consumption even on $21^{\text {st }}$. This was an indicative of the fact that $O$. sanctum extract had preventive effect on lipid peroxidation and hence enhance its shelf-life. This was due to the fact that mainly urolic acid, apigenin, and luteolin present in $O$. sanctum acted as anti-lipolytic factor due to which the shelf life of meat product was enhanced. This finding was in congruence with the finding of (Alo et al., 2012) who worked on properties of water, ethanol and methanol extract of $O$. sanctum. The plant extract had positive effect on lipid oxidation by reducing the production of 2-TBA and malondialdehyde formation in herbal extract incorporated meat product during refrigeration storage. The extract of various herbal plants and found out reduction in TBA value and lipid oxidation (Fasseas et al., 2007). Present findings were also supported that the incorporation of phenols and flavonoids in pork product reduced production of malondialdehyde and lowered TBA value (Tanabe et al., 2002).

FFA: The FFA value is quantitative indication of lipolysis in meat products. The FFA value of $O$. sanctum extract incorporated chicken nuggets recorded significantly lower $(\mathrm{p}>0.05)$ value in comparison to control product. This was an indicative of the fact that $O$. sanctum extract had preventive effect on lipolysis and hence enhance its shelf-life. The FFA value has increased significantly $(\mathrm{p}<0.05)$ on successive refrigeration storage days in $O$. sanctum extract incorporated chicken nuggets including control. This also suggested that $O$. sanctum extract incorporated chicken nuggets had better shelf life than control. It was due to the fact 
that urolic acid, apigenin, and luteolin present in extract of $O$. sanctum has anti-lipolytic activity due to and which free fatty acid production was less. It was supported by the work of (Yanpallewar et al., 2007) who worked on $O$. sanctum antioxidant and neuroprotective effect of $O$. sanctum on transient cerebral ischemia and long-term cerebral hypo perfusion. Our present finding was also supported by the finding of (Djenane et al., 2003) who concluded that surface application of extract of various herbs had positive effect on oxidative stability of beef steaks packaged in vacuum and modified atmospheric packaging. The present finding was also in parallel with finding of (Simitzis et al., 2008) who reported dietary natural antioxidants obtained from different herbs had positive effect on oxidative stability by producing fewer amounts of free fatty acids during refrigeration storage.

Microbiological characters: The changes in microbiological profile of $O$. sanctum extract fortified chicken nuggets at refrigeration temperature $\left(4 \pm 1^{\circ} \mathrm{C}\right)$ depicted in Table-2.

Total plate count: The total plate count was lowered in $O$. sanctum extract incorporated chicken nuggets than control. This was indicative of anti-microbial nature of $O$. sanctum extract. The total plate count was increased on successive refrigeration storage days in $O$. sanctum extract incorporate chicken nuggets including control. The TPC value of control chicken nuggets was indicative that the product was not suitable for human consumption on $21^{\text {st }}$ day of storage. The TPC value of $O$. sanctum .extract incorporated chicken nuggets were found to be in the range of $3 \log _{10} \mathrm{cfu} / \mathrm{gm}$ which was indicative of fact that $O$. sanctum . extract incorporated chicken nuggets were suitable for consumption even on $21^{\text {st }}$ day of refrigeration storage. The herbal extract had affected microbial cell by various antimicrobial mechanisms. It may disrupt enzyme system, disrupt genetic material of bacteria attacking on phospholipid bilayer cellular membrane and forming fatty acid hydro-peroxidase (Arques et al., 2008; Burt et al., 2007). The present finding was also supported by (Ceylan and Fung, 2004) who reported significantly decline in microbial load with incorporation of herbal extract in various meat product. The herbal extract had antimicrobial activity and when incorporated in meat product could elongate its shelf life during refrigeration storage. The urolic acid, apigenin, and luteolin active principal content in $O$ sanctum. extract was having broad spectrum antimicrobial activity (Alo et al., 2012).

Psychrotrophic count: Psychrotropic count was not detected till $7^{\text {th }}$ day of refrigeration storage. The psychrophilic were found to be lower on $14^{\text {th }}$ and $21^{\text {st }}$ day of refrigeration storage in $O$. sanctum. extract incorporated chicken nuggets as compare to control. It was also observed that control chicken nugget was not found to be suitable for consumption on $21^{\text {st }}$ day. However, $O$. sanctum. extract incorporated chicken nugget was found to be suitable for human consumption even on $21^{\text {st }}$ day of refrigeration storage. It may be due the fact that the principle component urolic acid, apigenin, and luteolin present in $O$. sanctum. extract had significant antimicrobial effect at refrigeration temperature. The apigenin, and luteolin interacted with phospholipid bilayer of microbial cell wall and cell membrane and disrupted it. It also defunct electron transport system, ion gradient and other enzyme dependent cellular mechanism of psychrotropic bacteria (Burt, 2004). The present result was also supported by finding (Rota et al., 2008) who suggested Psychrotropic antimicrobial affect of essential oils and extracts of herbal plants.

Coliform count: The coliform were not detected at any day of refrigeration storage in any of the product. It may be due to the fact that strict hygienic condition was followed during meat product processing. It may also be due to antimicrobial effect against coliform by urolic acid, apigenin, and luteolin present in $O$. sanctum. extract. Our present finding was supported by reports of (Ben Sassi et al., 2008; Graumann and Holley, 2008; Ibrahim et al., 2008; Kuete et al., 2008; Winward et al., 2008) who concluded that the extract and essential oil obtained from various herbs had significant antimicrobial effect against almost all coliforms.

Yeast and moulds: The yeast and Moulds count was not detected till $7^{\text {th }}$ day of storage but it was appeared in all product from $14^{\text {th }}$ day onward. The yeast and mould count of $O$. sanctum. extract incorporated chicken nuggets was significantly lower than control on $14^{\text {th }}$ and $21^{\text {st }}$ day of storage. It was also indicative of the fact that control chicken nugget was not suitable but $O$. sanctum extract incorporated chicken nuggets was found to be suitable for human consumption even on $21^{\text {st }}$ day of refrigeration storage. The appearance of yeast and moulds on $14^{\text {th }}$ day may be due to the fact that yeast and moulds requires incubation period of approximately 10 days. Moreover these extract possess natural fungicidal effect against food borne fungi (Fisher and Phillips, 2008; Daferere et al., 2000; Majhenic et al., 2007). Our finding was supported by (Razzaghi-Abyaneh et al., 2008; El. Seedi et al., 2008) who reported the ethanolic extract of $O$. sanctum and other herbs significantly reduces yeast and moulds count in various meat product. It was also effective against mycotoxin (Friedman, 2007; Musyimi et al., 2008; Kong et al., 2007; Lopez et al., 2007).

Sensory parameters: The changes in the sensory attributes of aerobically packaged $O$. sanctum. extract fortified Chicken nuggets during refrigerated storage at $4 \pm 1^{\circ} \mathrm{C}$ projected in Table 3 .

All the sensory attributes viz. color and appearance, flavour, texture, juiciness and overall acceptability was found to be lower on successive refrigeration storage in $O$. sanctum extract incorporated chicken nuggets including control. The color and appearance, flavour and juiciness of $3 \% O$. sanctum extract incorporated 
chicken nuggets was found to be significantly higher than $1 \%$ and $2 \%$ O. sanctum extract incorporated and control chicken nuggets. The texture value of $O$. sanctum extract incorporated and control chicken nuggets were comparable with each other. The Overall acceptability of 3\% incorporated $O$. sanctum extract in chicken nugget was higher than $1 \%$ and $2 \% O$ sanctum. extract incorporated and control chicken nuggets.

The control chicken nuggets have been quickly deteriorated on all parameters of sensory attributes as compared to O. sanctum. extract incorporated chicken nuggets. The $O$. sanctum extract incorporated chicken nuggets was found to be acceptable on the basis of sensory attributes even on $21^{\text {st }}$ day of refrigeration storage but the control chicken nuggets was rejected on $21^{\text {st }}$ day of refrigeration storage.

The herbal extract has positive effect by inhibiting discoloration and off-odor formation in different meat product during refrigeration storage (Djenane et al., 2003; Nerin et al., 2006; Camo et al., 2008). Natural antioxidant can positively affect color and appearance parameter and maintained the original color of product for longer duration during refrigeration storage (Djenane et al., 2003; Carpenter et al., 2007; Chouliars et al., 2007; Nerin et al., 2006 and Simitzis et al., 2008). The herbal extract can act as a very good flavoring agent. It can also act as a binding agent. The sensory character can also be enhanced with herbal extract incorporation in various meat products (Chaves et al., 2008).

\section{Conclusion}

The ethanolic: aqueous (80:20) extract of $O$ sanctum. was used in preparation of value added chicken nuggets. The developed product exhibited significant ( $\mathrm{p}>0.05)$ anti microbial, anti lipolytic and anti oxidant activity. The incorporation of $O$ sanctum. extract (3\%) in value added chicken nuggets has enhanced sensory scores as well as shelf life. The result revealed the possible application of $O$ sanctum. extract $(3 \%)$ as a natural source of anti oxidant in development of value added chicken meat product with potential health benefits.

\section{REFERENCES}

Alo, M.N., Anyim, C., Igwe, J.C., Elom, M. and Uchenna, D.S., (2012). Antibacterial activity of water, ethanol and methanol extracts of Ocimum gratissimum, Vernonia amygdalina and Aframomum melegueta. Adv. Appl. Sc. Res., 3 (2): 844-848

AOAC (1995). Official methods of analysis. $16^{\text {th }}$ edition. Association of official Agriculture Chemists, Washington, D.C.

APHA (1984). Compendium of methods for the microbiological examination of foods. $2^{\text {nd }}$ edn (ed. M.L. Speck). Americam Public Health Association, Washington, D.C.

Arques, J.L., Rodriguez, E., Nunez, M. and Medina, M. (2008). Inactivation of gram negative pathogens in refrigerated milk by reuterin in combination with nisin or the lacto peroxidase system. Eur. Food Res. Tech., 227 (1): $77-82$

Ben Sassi, A., Harzallah-Skhiri, F., Bourgougnon, N. and Aouni, M. (2008). Antimicrobial activities of four Tunisian Chrysanthemum species. Ind. J. Med. Res., 127: 183-192

Burt, S.A., Der Zee, R.V., Koets, A.P., De Graaff, A.M., Van Knapen, F. and Gaastra, W. (2007). Carvacrol induces heat shock protein 60 and inhibits synthesis of flagellin in Escherichia coli O157:H7. Appl. Environ. Micro., 73: 4484-4490

Camo, J., Beltrán, J.A. and Roncales, P. (2008). Extension of the display life of lamb with an antioxidant active packaging. Meat Sci., 80: 1086-1091

Carpenter, R., O'grady, M.N., O'callaghan, Y.C., O'brien, N.M. and Kerry, J.P. (2007). Evaluation of the antioxidant potential of grape seed and bearberry extracts in raw and cooked pork. Meat Sci., 76: 604-610

Ceylan, E. and Fung, D.Y.C. (2004). Antimicrobial activity of spices. J. Rapid Methods Automat. Micro., 12 (1): 155

Chaves, A.V., Stanford, K., Gibson, L.L., McAllister, T.A. and Benchaar, C. (2008). Effects of carvacrol and cinnamaldehyde on intake, rumen fermentation, growth performance, and carcass characteristics of growing lambs. Ani. Feed Sci. Tech., 145: 396-408

Chouliara, E., Karatapanis, A., Savvaidis, I.N. and Kontominas, M.G. (2007). Combined effect of oregano essential oil and modified atmosphere packaging on shelf-life extension of fresh chicken breast meat, stored at $4^{\circ} \mathrm{C}$. Food Micro., 24(6): 607-617

Daferera, D.J., Ziogas, B.N. and Polissiou, M.G. (2000). GCMS analysis of essential oils from some Greek aromatic plants and their fungi toxicity on Penicillium digitatum. J. Agri. Food Chem., 48(6): 2576-2581

Djenane, D., Sanchez-Escalante, A., Beltran, J.A. and Roncales. P. (2003). Extension of the shelf life of beef steaks packaged in a modified atmosphere by treatment with rosemary and displayed under UV-free lighting. Meat Sci., 64: 417-426

El-Seedi, H.R., Khattab, A., Gaara, A.H.M., Mohamed, T. K., Hassan, N.A. and Elkattan, A.E. (2008). Essential oil analysis of Micromeria nubigena and its antimicrobial activity. J. Essen. Oil Res., 20: 452-456

Fasseas, M.K., Mountzouris, K.C., Tarantilis, P.A., Polissiou, M. and Zervas, G. (2007). Antioxidant activity in meat treated with oregano and sage essential oils. Food Chem., 106(3): 1188-1194

Fisher, K. and Phillips, C. (2008). Potential antimicrobial uses of essential oils in food: Is citrus the answer. Trends Food Sci. Tech., 19(2): 156-164

Friedman, M., Henika, P.R., Levin, C.E. and Mandrell, R.E. (2007). Recipes for antimicrobial wine marinades against Bacillus cereus, Escherichia coli O157:H7, Listeria monocytogenes, and Salmonella enterica. J. Food Sci., 72(6): 207-213

Graumann, G.H. and Holley, R.A. (2008). Inhibition of Escherichia coli $\mathrm{O} 157: \mathrm{H} 7$ in ripening dry fermented sausage by ground yellow mustard. J. Food Prot., 71 (3): 486-493

Hannan, J.M.A., Marenah, L., Ali, L., Rokeya, B., Flatt, P.R. and Abdel-Wahab, Y.H.A. (2006). Ocimum sanctum leaf extracts stimulate insulin secretion from perfused 
pancreas, isolated islets and clonal pancreatic $\beta$-cells. $J$. Endocrino, 189: 127-136

Ibrahim, S.A., Yang, H. and Seo, C.W. (2008). Antimicrobial activity of lactic acid and copper on growth of Salmonella and Escherichia coli O157:H7 in laboratory medium and carrot juice. Food Chem., 109:137-143

Keeton, J.T. (1983). Effect of fat and $\mathrm{NaCl} /$ phosphate levels on the chemical and sensory properties of pork patties. J. Food Sci., 48: 878-881,885

Keller, J.E., Skelley, G.C. and Acton, J.C. (1974). Effect of meat particle size and casing diameter on summer sausage properties. J. Milk Food Tech., 37: 297-300

Kong, B., Wang, J. and Xiong, Y. L.(2007). Antimicrobial activity of several herb and spice extracts in culture medium and in vacuum-packaged pork. J. Food Protect., 70 (3): 641-647

Koniecko, E.S. (1979). Handbook for meat chemists. A very Pub Group Inc, Wayn, New Jersey.

Kuete, V., Tsafack Mbaveng, A., Tsaffack, M., Penlap Beng, V., Etoa, F.X. and Kengfack, N. (2008). Antitumor, antioxidant and antimicrobial activities of Bersamaengleriana (Melianthaceae). J. Ethnopharma, 115(3), 494501

Lanjewar R.D., Zanzad, A.A., Ramteke, B.N., Lalmuanpuii, Taksande, P.E. and Patankar, R.B., (2009). Incorporation of Tulsi (Ocimum sanctum) leaf powder in diet of broilers for quality meat production. Vet. World, 2(9): 340-342

Lopez, P., Sanchez, C., Battle, R. and Nerian, C. (2007). Vapor-phase activities of cinnamon, thyme, and oregano essential oils and key constituents against foodborne microorganisms. J. Agri. Food Chem., 55(11): 43484356

Majhenic, L., Skerget, M., Knez, Z. (2007). Antioxidant and antimicrobial activity of guarana seed extracts. Food Chem., 104(3): 1258-1268

Murthy K.N., Nagendra, K., Fazilath, U., Soumya, K. and Srinivas, C. (2014). Efficiency of Ocimum sanctum L. leaf extracts against bacterial wilt of tomato caused by Ralstonia solanacearum in tomato . Int. J. Curr. Micro. Appl. Sci., 3(12): 234-245

Musyimi, D.M., Muema, O., Muema, P.M. (2008). Phytochemical compounds and antimicrobial activity of extracts of aspilia plant (Aspilia mossambicensis) (Oliv) Wild. Int. J. Bot., 4(1): 56-61

Nerin, C., Tovar, L., Djenane, D., Camo, J., Beltran, J.A. and Roncales, P. (2006). Stabilization of beef meat by a new active packaging containing natural antioxidants. $J$.
Agri. Food Chem., 52: 5598-5605

Razzaghi-Abyaneh, M., Shams-Ghahfarokhi, M., Yoshinari, T., Rezaee, M.B., Jaimand, K. and Nagasawa, H. (2008) Inhibitory effects of Satureja hortensis L. essential oil on growth and aflatoxin production by Aspergillus parasiticus. Int. J. Food Micro., 123(3): 228-233

Rota, M.C., Herrera, A., Martinez, R.M., Sotomayor, J.A. and Jordan, M.J. (2008). Antimicrobial activity and chemical composition of Thymus vulgaris, Thymus zygis and Thymus hyemalis essential oils. Food Cont., 19: 681-687

Shan, B., Cai, Y.Z., Sun, M. and Corke, H. (2005). Antioxidant capacity of 26 spice extracts and characterization of their phenolic constituents. J. Agri. Food Chem., 53: 7749-7759

Simitzis, P.E., Deligeorgis, S.A., Bizelis, J.A., Dardamani, A., Theodosiou, I. and Fegeros, K., (2008). Effect of dietary oregano oil supplementation on lamb meat characteristics. Meat Sci., 79: 217-223

Simpson, T., Pase, M.L. and Stough, C. (2015). Bacopa monnieri as an Antioxidant therapy to reduce oxidative stress in the aging brain. Evid.-Based Compl. Alter. Med. Article ID 615384, 9 pages.

Snedecor, G.W. and Cochran, W.G. (1989) Statistical Methods. 8th edition. Ames, Iowa: Iowa State University Press. Pp-503.

Tajkarimi, M.M., Ibrahim, S.A. and Cliver, D.O. (2010). Antimicrobial herb and spice compounds in food. Food Control, 21: 1199-1218

Tanabe, H., Yoshida, M. and Tomita, N. (2002). Comparison of the antioxidant activities of 22 commonly culinary herbs and spices on the lipid oxidation of pork meat. Ani. Sci. J. 73: 389-393

Winward, G.P., Avery, L.M., Stephenson, T. and Jefferson, B. (2008). Essential oils for the disinfection of grey water. Water Res., 42(8-9), 2260-2268

Witte, V.C., Krause, G.F. and Bailey, M.E. (1970). A new extraction method for determining 2-Thiobarbituric acid value of beef during storage. J. Food Sci., 35: 582-585

Wojdylo, A., Oszmianski, J. and Czemerys, R. (2007). Antioxidant activity and phenolic compounds in 32 selected herbs. Food Chem., 105: 940-949

Yanpallewar, S.U., Raj, S., Kumar, M. and Achary, A. (2004). Evaluation of antioxidant and neuro-protective effect of Ocimum sanctum on transient cerebral ischemia and long-term cerebral hypo-perfusion. Biochem. Behaviour, 79: 155-164 